\title{
TANZANIA: THE AUTHORITARIAN LANDSLIDE
}

Pre-proofs version of paper accepted for publication in the April 2021 issue of the Journal of Democracy.

Version of the $8^{\text {th }}$ of March 2021. Includes subsequent updates made by the author on the $19^{\text {th }}$ of March 2021 after the death of President John Pombe Magufuli.

\author{
Dr. Dan Paget \\ Lecturer in Politics | University of Aberdeen
}

Website: danpaget.com | Email: daniel.paget@abdn.ac.uk | Twitter:@pandaget

ORCID ID: $\underline{0000-0002-3883-1649}$

\begin{abstract}
Dan Paget is a lecturer in politics at the University of Aberdeen. His essay "Tanzania: Shrinking Space and Opposition Protest" appeared in the July 2017 issue of the Journal of Democracy.
\end{abstract}

On 28 October 2020, Tanzania held a pivotal election. In one sense, no Tanzanian election has ever been pivotal. None has ever led to an alternation in power between government and opposition. Since it won independence from the United Kingdom in 1961, Tanzania has been ruled by the same party, now known as CCM (Chama Cha Mapinduzi, or the Party of the Revolution). Until 1992, CCM ruled through a formally single-party regime. Since then, it has ruled through an ostensibly multiparty regime by deploying authoritarian measures to maintain an electoral lead.

Regarding the bottom line, this approach has worked - CCM has won all its elections. Yet by 2015, the approach was proving increasingly unsustainable-CCM had steadily lost ground at the polls. In 2005, it won the presidential election with an unassailable 80 percent of the vote; the leading 
opposition candidate won only 12 percent. Ten years later, CCM's vote share fell to 58 percent, while the leading opposition candidate's rose to 40 percent. For all CCM's advantages, its support was shrinking.

In this sense, the 2020 election was pivotal. CCM rolled back its losses. President John Pombe Magufuli (1958-2021) won a second five-year term with 84 percent of the official vote, the highest share recorded in a presidential election since multipartyism was reintroduced three decades ago. In the parliamentary contests, CCM's gains were even more overwhelming. It won 93 percent of the elected seats in the National Assembly. ${ }^{1}$ The party had gained a similar proportion of the local-council seats, and 99 percent of the local-government positions in 2019. Altogether, CCM is now just digits away from being the only party to hold any elected offices. Tanzania's single-party history feels as contemporary as ever. ${ }^{2}$

The CCM sweep was an authoritarian landslide, achieved through electoral manipulation that was unprecedented in both scale and audacity. This was unaccompanied by high levels of violent oppression. One opposition report names fifteen people who were killed by state-security forces and paramilitary groups during and immediately after the campaign in Zanzibar. ${ }^{3}$ A subsequent, as yet unpublished report shared with me by another opposition party repeats thirteen of those fifteen names, and names twelve further people thus killed across Tanzania. ${ }^{4}$ These victim-lists have not been independently verified in their entirety, but Tanzania Election Watch (TEW), an independent panel of eminent persons from East Africa, gives a similar figure. It determines that altogether, at least 22 were killed. ${ }^{5}$ This all took place in a national climate that had become steadily more authoritarian since 2015.

This election, however, is not only significant because of the apparent electoral fraud perpetrated and harms wrought in its execution. It is significant for the turning point to which it 
amounts. It marks Tanzania's transition from a partly authoritarian regime in which electoral competition is permitted, to a fully authoritarian regime in which, de facto, it is not. Multipartyism has been pulverized. CCM domination has been forcibly restored.

On the 17th of March 2021, Magufuli died in office, just as this essay went to print. Magufuli was the public face of tyranny in Tanzania. His death raises the possibility, however faint, that CCM might alter the ultra-authoritarian course that it had chartered through the 2020 election. Yet in that course one can trace a new strategy of power. CCM used to use authoritarian actions to give itself a sufficient lead to carry elections. In 2020, however, the party far surpassed the plurality and majority thresholds of victory. Its goal was not merely to win the election, but to annihilate the opposition. In other words, one can read a rationale for a greater authoritarian turn into CCM's actions. While Magufuli is gone, the rationale remains. In fact, if anything, his death has only strengthened it.

The 2020 election and Magufuli's sudden demise will alter what politics takes place where in the future. Opposition will be driven abroad, online, and underground. Contests for power will further shift from the interparty to the intraparty realm. In sum, the 2020 election was a revelatory event. It shed light on what has happened, what CCM is doing now, and what is likely to come next.

\section{RIGGING THE ELECTION}

The struggle for power in Tanzania, Africa's fifth-largest nation, took place amid a struggle of ideas. In this struggle, President Magufuli took a major role. In his eyes, his election in 2015 had come at a critical moment for the nation. CCM had strayed from its historic mission by permitting too much economic privatization and political liberalization. This had made Tanzania prey to exploitation by domestic businesses and foreign imperialists. He also perceived CCM to be at a critical point, having lost support for two election cycles, as the Table shows. 
In 2015, Magufuli had presented his presidency as a break with the past. He had promised that there would be "only work here." He had launched a war against the "corrupt" on behalf of the "downtrodden." Some have interpreted this as the populist construction of a struggle between "the people" and "the [corrupt] elite," but Magufuli presented his project in subtly different terms. He envisaged corruption not at the pinnacle of his government, but beneath it in the depths of the ruling party, the bureaucracy, and the business world. He painted himself and CCM's top leadership as the steward or vanguard elite, whose role it was to root out "the corrupt" below them. ${ }^{7}$

Magufuli said that this house-cleaning would be the initial step in a campaign to restore the agenda of Julius Nyerere (1922-99), Tanzania’s first president. During his decades in power, between the early 1960s and the mid-1980s, Nyerere advocated "socialism and self-reliance." Magufuli selectively interpreted Nyerere's program, omitting its socialism while preserving the ideals of stateled developmentalism, national self-reliance, and at times, south-south cooperation. ${ }^{8}$ He and his party envisaged Nyerere's plan as the transformation of Tanzania into a modern, industrialized state free from dependence on foreigners. They delivered roads, dams, factories, trains, and even planes_they revived the national airline. It now flies De Havilland turboprops, Airbus jets and a pair of wide-body Boeing 787 Dreamliners out of renovated and expanded Julius Nyerere International Airport in Dar es Salaam. All these things were presented as icons of national development. ${ }^{9}$ The ruling party's 2020 campaign celebrated these achievements. The party's message was that it had delivered, but had more to do. The "only work here” slogan of 2015 turned into 2020’s “work continues."

The opposition embraced rival political projects. The second-largest opposition party, Alliance for Change and Transparency (ACT-Wazalendo) is led by Zitto Kabwe. From his stronghold in Kigoma (western Tanzania) he advocated the revival of Nyerere's project as socialist. Playing off Magufuli's slogan, he called for both "work and duck," or jobs and prosperity. ACT-Wazalendo was 
also the strongest opposition party in Zanzibar, the majority-Muslim nation that joined Tanganyika to form the United Republic of Tanzania in 1964. Nationalists from this semi-autonomous coastal archipelago, which is home to an estimated 1.7 million of Tanzania's 59.7 million people, were led by Seif Sharif Hamad until his death in February 2021. They demanded more independence from the union (Tanzania-wide) government for Zanzibar. They joined ACT-Wazalendo in 2019 after being marginalized in their previous party by a rival faction that the regime had assisted at every turn. ACTWazalendo nominated Hamad to run for the (subnational) presidency of Zanzibar.

The strongest opposition party on the mainland was the Party of Democracy and Development (known as Chadema, its Swahili acronym). Chadema made sizeable gains in the elections of 2010 and 2015. It lampooned CCM's cherished projects as so many white elephants. It criticized the ruling party's "development of things," and advocated instead the "development of people." As its 2020 standard-bearer, Chadema chose the outspoken lawyer, human-rights activist, and 2017 assassination-attempt survivor, Tundu Lissu.

Chadema and ACT-Wazalendo bridged their differences by finding a common cause: democracy. Midway through the campaign, they formed an informal electoral alliance that they presented as the united front of resistance against dictatorship. On this unofficial ticket, Lissu was the candidate for the presidency of Tanzania and Hamad for the presidency of Zanzibar. 
Table. Tanzanian National Election Results, 1995-2020

\begin{tabular}{llcc} 
Election & Party & Presidential & Parliamentary \\
\hline $\mathbf{1 9 9 5}$ & CCM & $61.8 \%$ & $80.2 \%$ \\
& Opposition & $38.2 \%$ & $19.8 \%$ \\
\hline $\mathbf{2 0 0 0}$ & CCM & $71.7 \%$ & $87.5 \%$ \\
& Opposition & $28.3 \%$ & $12.6 \%$ \\
\hline $\mathbf{2 0 0 5}$ & CCM & $80.3 \%$ & $88.8 \%$ \\
& Opposition & $19.7 \%$ & $11.2 \%$ \\
\hline $\mathbf{2 0 1 0}$ & CCM & $62.8 \%$ & $77.8 \%$ \\
& Opposition & $37.2 \%$ & $22.2 \%$ \\
\hline $\mathbf{2 0 1 5}$ & CCM & $58.5 \%$ & $73.4 \%$ \\
& Opposition & $41.5 \%$ & $26.6 \%$ \\
\hline $\mathbf{2 0 2 0}$ & CCM & $84.4 \%$ & $97.0 \%$ \\
& Opposition & $15.6 \%$ & $3.0 \%$
\end{tabular}

Notes: Results summarize the national share of the presidential vote and the share of directly elected parliamentary seats, excluding "special seats" allocated in proportion to national vote shares.

Opposition-party results are aggregated for simplicity. Numbers are rounded to one decimal place. Sources: Tanzania's National Electoral Commission and Sterling Roop and Keith Weghorst, “The 2015 National Elections in Tanzania," Electoral Studies 43 (April 2016): 190-94. Also see footnote number one.

Opposition and civic voices alleged that in 2020, any link between this struggle of ideas and the electoral struggle for power was severed. They claimed that the election had been a fraud. On social media and in press releases, they shared evidence of numerous forms of cheating. Their ability to observe and verify fraud systematically was impeded, however. First, opposition polling-place observers had been obstructed en masse, some denied accreditation in advance, others barred from entry. Lissu said that Chadema polling agents had been barred all day from about 57,900 of the 80,000 polling stations, and barred for part of the day from a further 12,000 stations. ${ }^{10}$ (These statistics have 
not been independently verified to my knowledge, though TEW determines that polling agent exclusion was "widespread".) A partial internet blockage came into effect on election eve and lasted until results were declared, which frustrated the timely-reporting of irregularities.

Second, the National Electoral Commission (NEC), which ought to be integral to the prevention and investigation of possible election fraud, lacks independence. Its members are nominally nonpartisan, but they are appointed and dismissed unilaterally by the president. Third, legal means cannot be used to address election fraud, because Article 74, Section 12 of the 1977 Constitution declares that "no court shall have power to inquire into anything done by the Electoral Commission in the discharge of its functions."

What about election observers? The state prohibited some domestic bodies from observing the 2020 election, notably Tanzania Episcopal Conference and the Legal and Human Rights Centre. It further broke with precedent by not responding to the EU's application to accredit an observer mission. The East African Community and the Southern African Development Community sent missions. In their preliminary statements, however, these gave the election a clean bill of health without so much as acknowledging the fraud allegations, other than to ask that stakeholders use legal channels to "settle any disputes." The Electoral Institute for Sustainable Democracy in Africa (EISA) also sent a mission, and alone voiced (limited) misgivings. Leaving aside that partial exception, it is hard to avoid the conclusion that CCM only allowed observers that were biased in its favor. Many of these irregularities are summarized in TEW's final report. ${ }^{11}$

The regime's foreclosure of every line of investigation made assessing the reality and scale of electoral fraud impossible. This enshrouding of the electoral process cut both ways: Electoral manipulation could not be verified, but neither could its absence. As a result, Tanzania's elections lost their integrity. Under such circumstances, the opposition's allegations should be granted prima facie 
credence. As verification has been precluded, the only means by which one can assess the validity of the election is judgment. With this in mind, the probability that CCM manipulated the results is increased by the magnitude of the victory that it officially claimed. The results show CCM not only coming close to erasing the opposition at the national level, but also piling up huge margins of victory in longtime opposition strongholds. This stretches the credibility of the election very thin indeed. It is far more likely that the government perpetrated large-scale rigging than that CCM pulled off such constituency-level swings.

\section{ENDING ELECTORAL COMPETITION}

At first glance, widespread electoral manipulation in Tanzania might seem unremarkable. After all, even as it reintroduced multiparty elections in 1992, CCM preserved much of the preceding authoritarian architecture, and has built on it since. Through it, CCM has remained fused with the state, which it runs in its own favor. State-led development is treated as CCM-led development. The

party monopolizes state rents, which supply funds for its election campaigns. ${ }^{12}$ It uses state ownership of media outlets and state regulatory powers over the media to guarantee itself favorable coverage.

The opposition, meanwhile, faces constant harassment. Its meetings broken up while the government accuses it of stoking civil strife. Opposition-friendly businesses are denied permits and state contracts, while opposition supporters find themselves cut off from access everyday state services and benefits. Critical autonomous associations are targeted for similar treatment. Supplementing this overt repression are covert campaigns of persecution involving abductions and low-level attacks. Such is the varied freight of CCM's authoritarian omnibus. In ways large and small, public and secret, it seeks to hobble its opponents. 
Before 2020, however, apparent electoral manipulation in Tanzania (at least on the mainland) remained limited. The ruling party found that its advantages brought ballot-box victories without the need for large-scale rigging. Despite many fraud allegations, available evidence suggests that rigging was selective rather than widespread. Yonatan Morse wrote in 2019 that "while Tanzanian elections are not clearly democratic, they are far from the stereotype of sham elections seen elsewhere."13 The 2020 election, therefore, marks a turning point. For the first time, there appears to have been systematic manipulation of a Tanzanian election at the national level.

In 2020, apparent electoral fraud went hand-in-hand with the intensification of the ruling party's other strategies of oppression. As I described in these pages four years ago, CCM initiated an authoritarian turn in 2015. The party was its original author and initiated it during the tenure of Magufuli's predecessor. Upon his election, Magufuli embraced and pursued it. ${ }^{14}$ This program began with legislation giving the state additional authority to silence journalists, civil associations, and civic activists. Officials made lavish use of these new powers, along with older ones, to quell dissent at a pace that broke with the recent past. The ruling party closed avenues by which opposition politicians could communicate with citizens. It asphyxiated their access to both new and old media. It tied them up in court cases and jail sentences. It banned rallies by all save sitting MPs.

Naked violence was part of the mix, too. Civic and opposition activists were frequently arrested, intimidated, and beaten by the police. "Unknown assailants" (many suspected to come from state-sponsored paramilitary groups) attacked, abducted, tortured, or killed CCM's critics. A pair of 2019 reports, one from Human Rights Watch and one from Amnesty International, catalogue these brutal curtailments of civic space. ${ }^{15}$ In this context, many opposition politicians, defected to CCM. Altogether, CCM oversaw a many-pronged authoritarian program that increased in extremity from 2015 until 2020. 
This greater authoritarian turn continued into the election campaign and its aftermath. Going into the 2019 local elections, Chadema declared a boycott of the polls after accusing officials of having spuriously disqualified 94 percent of its candidates. ACT-Wazalendo boycotted as well. In 2020, officials prevented many prospective opposition candidates from filing their nomination forms, and rejected many submitted forms. Opposition leaders told me that all told, Chadema had lost 63 prospective parliamentary candidates to these tactics, while ACT-Wazalendo had lost a hundred. (Of these, 36 from Chadema and at least 39 from ACT-Wazalendo won reinstatement on appeal.) ${ }^{16}$ Similarly, Chadema planned to run 3,754 local-council candidates, only to have more than a quarter $(1,020)$ kept off the ballot. Of these, only 165 managed to secure reinstatement.

The NEC issued campaigning bans of five and seven days, respectively, to Hamad and Lissu. After the results were announced, the opposition called for nationwide "peace marches," but these never materialized — a grim testament, perhaps, to what a campaign of midnight arrests and unbridled state force can do to suppress free assembly. Indeed, the unpublished Chadema report described above names - by my count - 314 persons whom the police took into custody in the election and surrounding period. Of these, 31 were denied bail, 88 were charged with unbailable offences, 122 were detained illegally, and 50 were tortured. It names a further 112 victims of violence, of whom 71 were assaulted, 37 were tortured and four disappeared. ${ }^{17}$ ACT-Wazalendo's report names further victims. After eliminating those named in both reports, it lists three further assaults, 131 further detentions, and 25 further abductions. ${ }^{18}$ These names and statistics have not been independently verified to my knowledge, but TEW corroborates the thrust of these findings. In response to this oppression, many opposition figures went into hiding.

The events of 2020 represented a sharpening of CCM's authoritarian turn. Past analyses interpreted CCM's authoritarian actions as the tilting of an already "unleveled playfield" (to borrow 
Alexander Makulilo's term) further in CCM's favor. Makulilo argues that the party-state militates against the "effective operations of opposition parties." 19 Nonetheless, without unduly idealizing the tenure of Magufuli's predecessors, ${ }^{20}$ analysts agree that CCM permitted at least minimal levels of competition and respected at least minimal civil and political liberties, albeit imperfectly. Analysts characterized Tanzania's regime not just as authoritarian, but competitive authoritarian, to capture this reality that a non-negligible amount of competition was permitted. ${ }^{21}$ How else could the opposition have gained such strength by 2015 ?

In the light of the 2020 election, such assessments need to be revised. The regime did not just grant itself a competitive advantage-it occluded competition altogether. It did not tilt the playing field; it closed the field and locked the gate. Tanzania went from a regime in which opposition and dissent were tolerated to one in which they were not. In political-science parlance, the system has metamorphosed from a competitive electoral authoritarian regime to a hegemonic one, ${ }^{22}$ or as Steven Levitsky and Lucan Way would call it, a "fully authoritarian regime."23 These changes have brought into being a state of affairs on the mainland that has long been a reality in Zanzibar, even as repression there has intensified still more.

It may be that this was CCM's strategy all along — that it always planned to fall back on rigging if it felt the need. If so, beneath this change of regime behavior lay a continuity of intent, of regime resolve. Intent is hard to observe, however. Often we can only infer it. In this case, the continuity in question hinges on a past conditional-What might CCM have done had it felt electorally threatened earlier? This casts the matter even further in the direction of the unknowable. This is one reason why regime typologies take behavior rather than intentions as their defining criteria. ${ }^{24}$ 


\section{BREAKING THE DYNAMIC}

Questions of classification aside, the ruling party's conduct during the election reveals something about its apparent intentions in 2020. Past analyses of CCM strategy interpreted the party's authoritarian behavior as a means to win elections. I myself wrote in these pages that CCM was "drastically narrow[ing] political space to reduce the likelihood of an opposition victory." 25 The goal of electoral victory was surpassed by such a wide margin in 2020, however, that assessments of CCM's activity should be rethought. Perhaps CCM overshot its goal out of simple miscalculation, or, as Ansbert Ngurumo suggests, out of paranoia. ${ }^{26}$ Or perhaps the scale of manipulation was the product of many lines of action, each initiated individually, that overdelivered collectively.

Tanzania's upper political echelons shroud their deliberations in a secrecy that outsiders rarely penetrate. Therefore, one can only speculate about CCM's true motives. Nonetheless, there is another possible explanation for CCM's actions that ascribes neither miscalculation nor coordination failure, but strategy. The premise of this explanation is that to ensure its longevity, an authoritarian regime should not just win elections, but win them sustainably. The key to sustainable winning, in turn, is discretion. That is, such regimes should use authoritarian methods that are covert rather than overt. ${ }^{27}$

If, however, the opposition grows popular despite all the regime's discreet methods, as happened in Tanzania, the regime's viability comes into question. Either it can accept the prospect of losing elections, or it can resort to blatant methods such as widespread rigging. Such conspicuous manipulation, however, may provoke opposition protest. Then the regime faces a second unpalatable choice: It can respond with repression, which will erode its legitimacy, or it can make concessions, which will erode its power. Either way, it will be starting a cycle that is likely to recur. Thereby, the regime becomes locked into an unsustainable dynamic like that theorized by Andreas Schedler. ${ }^{28}$ 
There were two pertinent reasons for CCM to have concluded that it was on such a path. The first was Zanzibar. The cycle of opposition gains, rigging, protest, and electoral reforms of successive Zanzibari elections closely resembled one variant of the sequence described above. The second was Chadema. Between 2006 and 2015, Chadema not only became popular; it organized. Through this apparatus, it met and matched the canvassing effort of the famously well-organized CCM in $2015 .^{29}$

Many speculated that Magufuli's mood-catching platform and authoritarian program would cut deeply into the opposition's popularity. This could not be confirmed or rejected through surveys, because Tanzanian respondents overreport CCM support to survey takers, and because in 2018 CCM put a de facto ban on opinion polls. This kept the question of opposition popularity open. In this context, Chadema held rallies which, at first sight, were comparable in size to both its 2015 rallies and CCM's own. So did ACT-Wazalendo in Zanzibar. Rallies are poor bellwethers of popular support even in Tanzania, which has the most rally-intensive campaigns in the world. Nonetheless, Chadema's rallies were consistently large enough to support this negative inference: Chadema and ACTWazalendo support had not collapsed. Whatever their true popularity, at least some core of their support had endured despite everything CCM had thrown into the effort to undercut it.

For CCM, this raised a chilling possibility: The opposition had become indomitable. The more CCM tried to tilt the field and take the high ground, the harder the opposition would eventually climb. The heavier CCM cracked down, the stronger the opposition would rise up. This is the spirit of indefatigable rebellion that Lissu sometimes captured in his outspoken presidential campaign. If this were the case, then CCM would no longer have a sustainable means of allowing electoral competition while continuing to ensure itself of winning. It would be on the brink of the cycle of rigging and protest followed by repression or reform that would incrementally undermine its rule. 
Grasping this, CCM may have resolved on extraordinary measures to break out of this dynamic. This provides a rationale that is consistent with CCM's actions. In order to avoid a future in which it would lose power, CCM may have sought to make a future opposition victory seem not merely unlikely, but impossible.

The regime's actions in 2020 narrowed the opposition's apparent possibilities on several levels. On a practical level, the opposition's exclusion from elected offices left it starved of the salaries, localgovernment posts, and media coverage on which it thrived. ${ }^{30}$ On the level of appearances, CCM's astounding showing gave it an unprecedented mandate. The towering results painted CCM as unassailably popular and the opposition as ruinously unpopular. This lengthened the odds against a near-term opposition victory. On a third level, the apparent scale of electoral manipulation tacitly told the opposition of CCM's resolve: The regime will grant itself landslides, come what may. Similarly, the audacity of CCM's actions displayed its impunity. It could stuff ballots and shoot protestors without fear of sanction.

The actions of CCM affect not only the near-term but the long-term prospects of opposition victory. A common opposition strategy is to respond to rigging with protest to bounce authoritarian regimes into electoral reforms. This presupposes, however, that the regime will choose reform over exposure and violence. By rigging elections audaciously and crushing protests violently, CCM held its hand to the flame. It showed itself willing to absorb the worst costs that the opposition could ever inflict upon it, and thus signaled that there was no way the opposition could make it adopt electoral reforms.

On each of these levels, CCM has sent the same implicit message: It will never, ever be beaten. If opposition activists read and accept this message, they may give up and disband. They risk hardships because they have hope. If CCM makes opposition seem futile, it makes activism not only hazardous 
but hopeless. This demobilizing message would undo the organizational and ideational progress that the opposition has made over the last fifteen years. For CCM, this would be an achievement worthy of Houdini. It would deliver the party from the trap of rigging and protest followed by repression or reform in which it was gradually being ensnared. In light of such a strategy, the apparent magnitude and brazenness of CCM's authoritarian conduct would make sense. This strategy supposes that rising opposition strength had made CCM's prior strategy unsustainable, and that a massive act of domination would break the opposition's spirit and restore the sustainability of its rule.

Ultimately, it remains a matter of speculation whether CCM decided to adopt its ultraauthoritarian course out of error, fear, or strategy. President Magufuli, however, had a record of decisiveness and strategic ingenuity which is consistent with this account of events. This record plus CCM's six decades in power all makes it more likely (in the absence of conclusive evidence either way) that the regime's actions are a matter more of method than mistake.

Assuming what I have described above to be CCM's rationale, it would have been formulated amid a changing international context. As African countries made transitions to multipartism following the Cold War, Western countries exercised considerable power. They compelled African states to enact successive neoliberal economic reforms, and to adhere to democratic constitutions. Three decades on, Western power has ebbed. In an increasingly multipolar world, African states need support from Western ones less. Those Western states, meanwhile, place increasingly more emphasis on economic gain and less on democracy promotion in their foreign policies. This adds up to a West that has lost its appetite for confrontations with autocratizing African regimes.

Since 2015, CCM has repeatedly tested the resolve of Western states and transnational bodies as it has enacted its authoritarian program. With each step, the party has found them hesitant to act. In fact, CCM has limited freedoms, cut off political competition, and inflated its own power without 
meeting much more than token and fleeting Western resistance. If CCM's shift from competitive to hegemonic authoritarianism turned on a cost-benefit analysis, the record of Western inaction clearly reduced the apparent costs.

To say that CCM may have chosen its authoritarian direction strategically is not to say that it reduced the possible courses, costs, and benefits to matters of regime survival. There is an ideology that informs CCM's perspective, and Magufuli was its prime exponent. He presents national industrial transformation as an imperative and condemns dissent and opposition as inimical to it. In this view, political competition and criticism disrupt the peace, distract from governing, breed unconstructive complaints, and empower big business. Altogether, they impede the realization of "New Tanzania." Magufuli constantly warns politicians to refrain from what he calls "politics" (meaning contestation) and tells them to focus on development.

To the extent that Magufuli advocated democracy at all, it is a tamed democracy that partly resembles the so-called single-party democracy instituted by the very man whose legacy he claimed to be restoring: Julius Nyerere. It may be that Magufuli and CCM were cynics who do not believe their own rhetoric. Yet it could be the case that they viewed their options through this ideological lens, and saw political competition as not only bad for their sustained rule, but also as bad for the restoration of Nyerere's Tanzania. Therefore, 2020's greater authoritarian turn may have been strategic and ideological all at once.

\section{AUTHORITARIAN FUTURES}

Magufuli's death raises the prospect of change in Tanzania's authoritarian trajectory. This possibility depends on whether his death alters the rationales for CCM's ultra-authoritarian strategy. Magufuli's succession could precipitate a realignment, however partial, in CCM's leadership. If by 
chance or challenge that realignment elevated politicians that do not share Magufuli's ideological appetite for authoritarianism, these new leaders might initiate democratic reforms. They may also inadvertently create a column of "soft-liners" that weaken the regime's resolve in future confrontations with the opposition.

Nonetheless, the strategic rationale for the authoritarian turn remains. Magufuli's death does not diminish the possibility of opposition recovery. Nor does it make CCM's prior power strategy more sustainable. The 2020 election makes the reasons for CCM to stay the course even stronger by giving regime personnel more to fear from investigation and prosecution that would follow any opposition victory. Magufuli's death only compounds the reasons to continue the authoritarian turn. First, his popularity lifted CCM's popularity. Without him, it will be even harder for CCM to sustainably win elections without manipulating them. Second, the opposition may seek to test the new leadership and expose any loss of resolve. Knowing this, Magufuli's successors will have reason to crack-down harder to show strength. A change of leadership is nonetheless a rhetorical opportunity to signal change. The regime may use the presidential succession to feign concessions to ameliorate its critics at home and abroad. Therefore, Magufuli's death may lead to tokens of democratic reform, even if no substantive reforms follow.

Whether or not Magufuli's death leads to a change in how the regime rules, it is likely to reignite struggles within the regime about who rules. In doing so, it will accelerate long-term changes set in motion over the last six years. CCM has long been a site of factional struggle. By 2015, amorphous yet potent factions had developed inside $\mathrm{CCM}^{31}{ }^{31}$ By 2015, these factions were evenly matched and recurrently at war. Magufuli broke this balance of factions and recentralized power in the party and state. ${ }^{32}$ By 2020, his authority within the party seemed nearly absolute. Put otherwise, he had become the central column around which hung the regime's web of alliances. With his death, that web will 
collapse. This will create a moment of struggle as factions vie over how a new one is spun. Whatever the outcome of this jostling for position, the authoritarian turn over which Magufuli presided will compound the likely intensity of future moments of factional struggle, for three reasons. First, the authoritarian landslide of 2020 gives CCM politicians greater to scope to fight one another without jeopardizing their party's position. Second, by concentrating further powers in the presidency, especially over economic rents, Magufuli raised the stakes of factional competition. Third, he drew the security organs further into the regime's internal politics.

The 2020 election also shapes the possible futures of the Tanzanian opposition, which now finds itself in a struggle for survival, with no certain outcome. It will have to learn to operate in the hostile environment that CCM has reinforced since 2015. Sustaining the vigor of demoralized opposition activists will be no small feat. To do so, the opposition must straddle a contradiction: By invoking the extremity of CCM's authoritarianism, the opposition vindicates its democratic argument, but also underscores the futility of resistance. The ruling party's 2020 act of domination poisons the opposition's cause. It makes the chief reason to join the struggle also the chief reason to forsake it. The opposition will have to navigate this rhetorical tension amid new questions about which party leads it, now that the conventional principle of "most votes and seats" no longer answers. These questions are exacerbated by CCM's continued attempts to "divide and conquer."

While it is unclear how the opposition will fare after 2020, it is clearer where opposition activities will increasingly take place. Denied access to mass media, rallies, and official posts, opposition activists will continue to move online. ${ }^{33}$ Meanwhile, they will double down on door-todoor politics, which can be conducted covertly. Yet their wavering members will be reluctant to venture into streets that are increasingly hostile. 
In addition to going online and underground, opposition will go international. Voices in the diaspora will grow stronger, not only because they alone are beyond the reach of the Tanzanian state, but also because many opposition activists have fled Tanzania. There are non-Tanzanian allies to be found abroad too. A number of foreign media outlets, activists, NGOs, and scholars have become vocal critics of CCM authoritarianism and, in some cases, proponents of the opposition. The opposition will also continue to seek the support of multilateral institutions and foreign nations alike. "We are asking governments and international organizations," said Lissu, "to impose targeted sanctions, asset freezes and such measures as necessary to put an end to the impunity which has characterized the regime." 34 Perhaps in response, the United States imposed visa restrictions on unnamed Tanzanian officials responsible for or complicit in electoral fraud.

I will close by remarking on the significance of Tanzania's 2020 election further afield. Africa, like much of the world, is experiencing a wave of autocratization. Since 2015, Tanzania has repeatedly defied democratic norms. Each time, he has met little Western or transnational resistance. This reveals that those norms are, apparently, toothless. Autocrats old (such as Uganda's Yoweri Museveni) and new (such as Zambia's Edgar Lungu) watch Tanzania as they gauge their own latitude to act.

Eastern and southern Africa are checkered with regimes that were born of violent liberation struggles. These postliberation regimes are among the longest-lived and most authoritarian in the region. They pursue varying projects, but share a commitment to postponing and taming democracy in pursuit of their liberatory programs. Tanzania won its liberation with little violent struggle, at least on the mainland. Nonetheless, its regime has endured longer than any postliberation regime. Furthermore, Tanzania played a major part in other African struggles for liberation from European colonialism and white-supremacist regimes. 
Although CCM is seen as a founding member of the liberation club, it was also widely thought to have forsaken any radical agenda. Magufuli's stylized reinstatement of President Nyerere's mission has raised the possibility that Tanzania is "returning to the fold." (Looking further afield, Magufuli's move also partly mirrors Xi Jinping's invocation of the figure of Mao Zedong to justify intensified autocratization in China.) Postliberation regimes will interpret the 2020 election as a restoration of Tanzania's liberatory character. Time alone will tell whether this symbolic reembracing of revolution further imbues the CCM regime with the durability that we have come to associate with postrevolutionary regimes. ${ }^{35}$

\section{NOTES}

1. The unicameral National Assembly contains 393 seats. Of these, 264 are seats to which candidates are elected by plurality from single-member districts (SMDs). A further 113 "special seats" are allocated in proportion to parties' respective vote shares by drawing from all-female party lists. The remaining sixteen seats are held by the attorney-general, five members sent by the legislature of Zanzibar, and ten named by the president of Tanzania. Complete official results are unavailable, but study of numerous sources indicates that CCM won 256 SMDs and 94 special seats. ACT-Wazalendo won four seats, the Civic United Front (CUF) won three, and Chadema won a single seat. Contradictory figures for the total number of opposition MPs are in circulation, so for clarity's sake, here are those MPs' names and constituencies. ACT-Wazalendo: Khatib Said Haji (Konde), Omar Ali Omar (Wete), Khalifa Mohammed Issa (Mtambwe), and Salim Mohammed Shafi (Chonga). CUF: Shamsia Azizi (Mtwara Viijiini), Seif Salim Seif (Mtambile), and Maryam Omar 
(Pandani). Chadema: Aida Khenan (Nkasi Kaskazini). The remaining nineteen special seats went to Chadema, but in protest it refused to submit names for them. The National Assembly speaker picked Chadema members to fill the seats. They accepted, Chadema expelled them, and they continue to hold the Chadema seats. Special thanks to Jesca Kishoa (MP), Pavu Abdallah and Janeth Rithe (ACT-Wazalendo), Deogratias Munishi (Chadema), Sammy Awami and those they contacted for helping to determine these details.

2. Michaela Collord, “Tanzania’s 2020 Election: Return of the One-Party State,” Sub-Saharan Africa Center, Institut Français des Relations Internationales, February 2021, www.ifri.org/sites/default/files/atoms/files/collord_tanzania_2020_election_2021.pdf.

3. ACT-Wazalendo, “Human Rights Report,” 21 November 2020: 7-8, www.actwazalendo.or.tr/act_wazalendo_human_rights_report.

4. Chadema, "Election Violence Brief," unpubl. report, December 2020.

5. Tanzania Election Watch, Final Observation Report on the General Elections Held in Tanzania on October 28, 2020: Not Free, Not Fair (2021): 58, www.khrc.or.ke/publications.html

6. Thabit Jacob and Rasmus Hundsbæk Pedersen, "New Resource Nationalism? Continuity and Change in Tanzania's Extractive Industries," Extractive Industries and Society 5 (April 2018): 287-92.

7. Dan Paget, "Mistaken for Populism: Magufuli, Ambiguity and Elitist Plebeianism in Tanzania," Journal of Political Ideologies, published online 4 August 2020, www.tandfonline.com/doi/full/10.1080/13569317.2020.1796345. 
8. Lisa Richey, Line Engbo Gissel, Opportuna Kweka, Pernille Bærendtsen, Peter Kragelund, Herbert Qambalo Hambati, and Asubisye Mwamfupe, "South-South Humanitarianism: The Case of Covid-Organics in Tanzania," World Development 141 (2021): Article 105375, wmw.sciencedirect.com/science/article/pii/S0305750X20305039.

9. Dan Paget, “Again, Making Tanzania Great: Magufuli’s Restorationist Developmental Nationalism," Democratization 27, no. 7 (2020): 1240-60.

10. Patrick Smith, “Tanzania’s Tundu Lissu: 'We're Completely Unbroken-Bruised and Battered, Yes_But Unbroken," Africa Report, 13 January 2021, wnw. theafricareport.com/58715/tanzanias-tundu-lissu-were-completely-unbroken-bruised-and-battered-yes-butunbroken.

11. Tanzania Election Watch, Final Observation Report.

12. Edwin Babeiya, "Electoral Corruption and the Politics of Elections Financing in Tanzania," Journal of Politics and Law 4, no. 2 (2011): 91-103.

13. Yonathan Morse, How Autocrats Compete: Parties, Patrons, and Unfair Elections in Africa (Cambridge: Cambridge University Press, 2019), 2.

14. Dan Paget, “Tanzania: Shrinking Space and Opposition Protest," Journal of Democracy 28 (October 2017): 153-67.

15. “'As Long as I Am Quiet, I Am Safe': Threats to Independent Media and Civil Society in Tanzania,” Human Rights Watch, 28 October 2019; “The Price We Pay: Targeted for Dissent by the Tanzanian State,” Amnesty International, 28 October 2019. 
16. Author's phone call with Deogratias Munishi, Chadema head of foreign affairs, 5 December 2020, and WhatsApp message from him of 24 February 2021; Pavu Abdallah, ACT-Wazalendo deputy secretary of human rights and special groups, WhatsApp message, 6 December 2020; see also International Democratic Union, "Resolution on Tanzania,”16 December 2020, wmw.idu.org/resolution-on-tanzania.

17. Chadema, "Election Violence Brief." This excludes six possible duplicates. Thanks to Munishi for answering clarificatory questions.

18. ACT-Wazalendo, "Human Rights Report.” Thanks to Rithe and Abdallah for answering clarificatory questions. A number of possible duplicates were excluded from ACT-Wazalendo's lists. A related query was outstanding at the print deadline, so these figures may underestimate those numbers.

19. Alexander Boniface Makulilo, "Unleveled Playfield and Democracy in Tanzania," Journal of Politics and Law 5, no. 2 (2012): 96.

20 This point is made by Sabatho Nyamsenda, “Q\&A with Sabatho Nyamsenda on Magufuli's Re-election," UDADISI, 4 November 2020, www.udadisi.org/2020/11/q-with-sabatho-nyamsenda-onmagufulis.html.

21. Marie-Aude Fouéré and Cyrielle Maingraud-Martinaud, “Une hégémonie compétitive contre vents et marées : les élections générales de 2015 en Tanzanie et à Zanzibar," Politique Africaine 140, no. 4 (2015): 145-63. 
22. Larry Diamond, "Elections Without Democracy: Thinking About Hybrid Regimes," Journal of Democracy 13 (April 2002): 21-35.

23. Steven Levitsky and Lucan A. Way, Competitive Authoritarianism: Hybrid Regimes After the Cold War (New York: Cambridge University Press, 2010).

24. Levitsky and Way, Competitive Authoritarianism.

25. Paget, “Tanzania: Shrinking Space and Opposition Protest:” 159.

26. Ansbert Ngurumo, John Magufuli: An Epitome of Cowardice (Bloomington, Indiana: AuthorHouse, 2019).

27. Nic Cheeseman and Brian Klaas, How to Rig an Election (Yale University Press, 2018): 33.

28. Andreas Schedler, “The Nested Game of Democratization by Elections," International Political Science Review 23 (January 2002): 103-22.

29. Dan Paget, "The Authoritarian Origins of Well-Organised Opposition Parties: The Rise of Chadema in Tanzania," African Affairs 118, no. 476 (2019): 692-711.

30. Rachael McLellan, "The Politics of Local Control in Electoral Autocracies," doctoral diss., Princeton University, 2020.

31. Michaela Collord, “Authoritarian Party (Dis)continuities: The Case of Tanzania’s President Magufuli and the "New" Chama Cha Mapinduzi," unpubl. ms., 2021.

32. Rasmus Hundsbæk Pedersen, Thabit Jacob, and Peter Bofin, "From Moderate to Radical Resource Nationalism in the Boom Era: Pockets of Effectiveness Under Stress in 'New Oil' 
Tanzania," Extractive Industries and Society 7 (November 2020): 1211-18; Collord, “Authoritarian Party (Dis)continuities."

33. Aikande Kwayu, "Determinants of Political Party's Social Media Strategy: A Comparative Analysis of Tanzania’s Opposition Political Parties’ Twitter Practices,” unpubl. ms., 2021.

34. “Tundu Lissu and Zitto Kabwe International Press Conference,” 23 November 2020, wmw.youtube.com/watch?v=jMt_niucc9M.

35. Steven Levitsky and Lucan Way, “The Durability of Revolutionary Regimes,” Journal of Democracy 24 (October 2013): 5-17. 